\title{
Year-class strength of plaice Pleuronectes platessa in the Southern Bight of the North Sea: a validation and analysis of the inverse relationship with winter seawater temperature
}

\author{
Henk W. van der Veer*, Johannes IJ. Witte \\ Netherlands Institute for Sea Research (NIOZ), PO Box 59, 1790 AB Den Burg Texel, The Netherlands
}

\begin{abstract}
The previously (1974-1982) observed inverse relationship between the February seawater temperature at the spawning grounds in the Southern Bight of the North Sea and subsequent year-class strength of 0-group plaice on the Balgzand tidal flats (western Dutch Wadden Sea) was revalidated for the period 1991-1998. However, seawater temperatures determined from NOAA satellite images showed that water temperatures during egg and larval drift in the open sea were more constant than the February temperatures at the spawning grounds suggested. In all years, and under all conditions, there was a persistent tongue of English Channel water entering through the Dover Strait into the Southern Bight of the North Sea, in which plaice eggs and larvae developed and were transported. The intensity of this plume varied between years, but even during the coldest period it penetrated as far as offshore Texel and the Marsdiep inlet. The absence of interruptions in the pattern of larval immigrations at the nursery implies a link between variations in water temperatures and in the period of drift. Between and within years, the number of settling larvae at Balgzand was inversely related to the median temperature during drift. Overall, also year-class strength estimates were still inversely related to water temperature during drift. However, the relationship broke down for the very strong 1996 yearclass, suggesting that other factors were acting too. Cold winters (reflected in low temperatures in the coastal zone) are associated with persistent winds from the east which induce an atypical water circulation pattern that affects the strength and direction of the residual current. Easterly winds might also generate upwelling near the coast stimulating larval immigration.
\end{abstract}

KEY WORDS: Pleuronectes platessa - Flatfish $\cdot$ Hydrography $\cdot$ North Sea $\cdot$ Water temperature $\cdot$ Yearclass strength $\cdot$ NOAA satellite images

\section{INTRODUCTION}

One of the main spawning areas of plaice Pleuronectes platessa L. is located in the Southern Bight of the North Sea. Plaice spawn in this area in January to February and the developing eggs and larvae are transported by residual currents towards nursery areas along the Dutch and German coasts (Simpson 1959 , Harding \& Talbot 1973, Talbot 1976, 1978, Harding et al. 1978). Due to the shallow depth and its strong tidal currents in the Southern Bight, egg and larval drift

•E-mail: veer@nioz.nl occurs in completely mixed water masses offshore in the zone of maximum salinity and minimum turbidity (Cushing 1990, Otto et al. 1990). On the nursery grounds, the larvae settle at a size of between 10 and $15 \mathrm{~mm}$, and take up a demersal way of life (Creutzberg et al. 1978, van der Veer 1986).

In the mid-1980s, results of extensive investigations indicated that the year-class strength of Southern Bight plaice was determined during the early pelagic stages. Brander \& Houghton (1982) based their conclusion on the analysis of egg and larval surveys and Zijlstra et al. (1982) and van der Veer (1986) on the study of late larvae and early juvenile plaice at a tidal flat (Balgzand) in the Dutch Wadden Sea. Furthermore, 
year-class strength of plaice appeared to be inversely related to temperature conditions at the spawning ground (van der Veer 1986). However, there were no differences in morphological stage, size or timing of larval immigration between years, despite the substantial interannual differences in water temperature (van der Veer 1986). This problem remained unresolved. The underlying mechanisms of the inverse relationship between temperature and year-class strength is not clear. There is the possibility that the inverse correlation may simply be fortuitous, as has been shown for many other updated environmentally based recruitment models (Frank 1991). Therefore, this relationship needs to be validated with a new independent data set, as stressed by Gulland (1965) and Bailey (1994).

The aims of this paper are 2-fold: (1) a validation of the inverse relationship between water temperature at the spawning grounds and subsequent year-class strength of plaice, and (2) an analysis of the apparent discrepancy that despite the interannual differences in temperature no differences between years are found with respect to morphological stage, larval size at the time of immigration or the timing of immigration. In previous studies, water temperature measurements represented observations originating from cruise surveys or other types of sampling stations at sea (lightvessels) or along the coast. During that time, synoptic mapping of water temperature was not possible. In the present study the same sampling stations were taken, but in addition the sea surface temperature images from the TIROS-N satellites operated by NOAA were analysed, in combination with published information on egg and larval development in relation to temperature (Ryland 1966, Ryland et al. 1975). Juvenile flatfish data were collected in the same study area as sampled by Zijlstra et al. (1982) and van der Veer (1986): the Balgzand area, a main nursery area in the western part of the Dutch Wadden Sea.

\section{MATERIAL AND METHODS}

Water temperature data. Two data sets were used: field measurements and satellite images of the southern North Sea. Field measurements were available for a number of locations in the southern North Sea (Fig. 1):

(1) Southern Bight plaice spawning ground. The centre of the spawning ground is at $51^{\circ} 51^{\prime} \mathrm{N}$ and $2^{\circ} 50^{\prime} \mathrm{E}$. February water temperatures were published by Harding et al. (1978). Data were taken for the years 1947 to 1973.

(2) Lightvessel 'Noordhinder' The lightvessel was in operation from 1886 to 1982 almost continuously. From 1973 to 1982 the lightvessel was located at 51 $39^{\prime} \mathrm{N}$
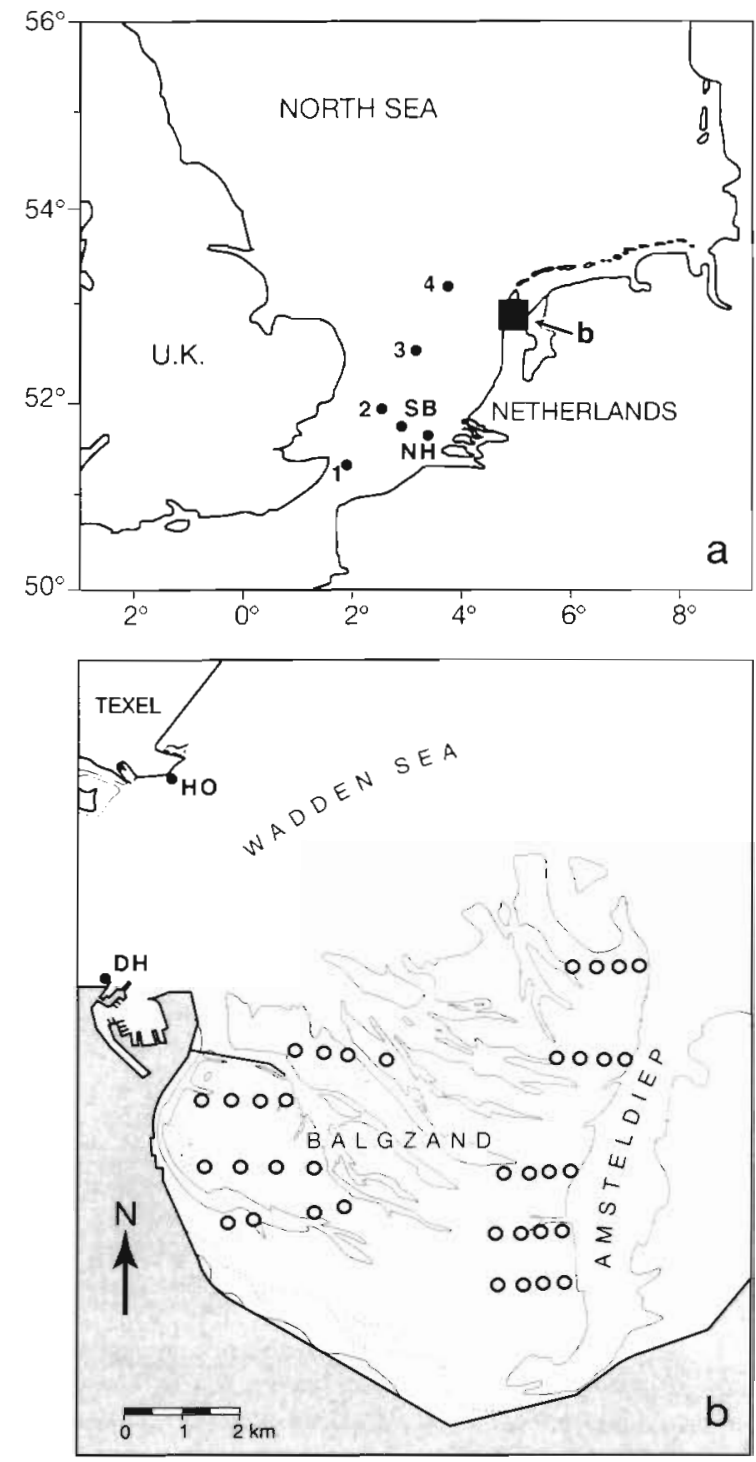

Fig. 1. (a) Water temperature sampling stations in the southern North Sea (SB: Southern Bight spawning ground; $\mathrm{NH}$ : Lightvessel. 'Noordhinder') together with NOAA satellite stations (Stns 1 to 4 ). (b) The Balgzand tidal flat area, together with flatfish sampling stations (0). DH: Den Helder HO: 't Horntje

and about $2^{\circ} 34^{\prime} E$. Surface water temperature was collected on a daily basis. Mean monthly seawater temperatures were published by van der Hoeven (1984a).

(3) Den Helder and 't Horntje. On both sides of the Marsdiep - the westernmost inlet of the Dutch Wadden Sea-daily water temperatures have been recorded. In Den Helder $\left(52^{\circ} 58^{\prime} \mathrm{N}, 4^{\circ} 47^{\prime} \mathrm{E}\right)$, measurements started in 1860 and mean monthly surface values of the period 1860 to 1984 were published by van der Hoeven (1984b). 't Horntje (53 00' N, $4^{\circ} 48^{\prime}$ E) is a sampling station on the southern part of the isle of 
Texel on the northern side of the Marsdiep inlet. Data collection started in 1947 by NIOZ (unpubl.) and surface water temperatures are available on a daily basis.

Satellite images of sea surface temperatures of the southern North Sea were obtained for the period January to June for the years 1991 to 1997 (1992 excluded) from composites of reflectance images from the Advanced Very High Resolution Radiometer sensor (AVHRR), installed on board the TIROS-N satellites. Each day, 2 to 4 images of the infrared reflected from the North Sea surface were produced with a spatial resolution of $1.1 \mathrm{~km}^{2}$ directly below the satellite. The raw data were corrected for transmission through the ozone layer, Raleigh scattering and aerosol scattering on the basis of algorithms developed for the Coastal Zone Color Scanner (Roozekrans \& Prangsma 1988). Daytime images were omitted to prevent a bias by heating of the sea surface by sun irradiation. Mean seawater temperature (accuracy $\pm 0.6^{\circ} \mathrm{C}$ ) was determined from weekly composites over the period January to June for the locations of the lightvessel 'Noordhinder' and 4 stations on a transect between the spawning area and the Marsdiep inlet (Fig. 1, Table 1) in the area of plaice egg and larval drift (Talbot 1978). Monthly composites of night images were also compiled for the period January-June 1991 to 1997 (1992 excluded).

Flatfish data. Demersal fishing was carried out at the same sampling stations (Balgzand, a large isolated tidal flat system in the western Wadden Sea) (Fig. 1b) and with the same methods as in the period 1974-1982 (Zijlstra et al. 1982, van der Veer 1986). In short, fishing was carried out at frequent intervals ( 2 to $4 \mathrm{wk}$ ) on a grid of 36 stations distributed over the area. Hauls of about $100 \mathrm{~m}$ in length were undertaken at high water during daytime with a $1.9 \mathrm{~m}$ beam trawl (1 tickler chain, net mesh size of $5 \times 5 \mathrm{~mm}$ ) towed by a rubber dinghy with a $25 \mathrm{hp}$ outboard motor at a speed of approximately $35 \mathrm{~m} \mathrm{~min}^{-1}$ (Riley \& Corlett 1966). Location of the hauls was established by GPS and the length of the hauls was assessed with a meter-wheel fitted to the trawl. In 1991, fishing was done only in April-May during the period of settlement to establish the maximum density. In 1993 to 1998 fishing was performed between February and August. Catches were deep frozen and then sorted within a few days. 0 -group plaice was preserved in $70 \%$ ethanol and the total length was measured to the nearest mm. Numbers caught were corrected for size-selective mesh and catch efficiency after Kuipers (1975) and Dapper (1978) and converted into numbers per $1000 \mathrm{~m}^{2}$ (ind. $\left[10^{3} \mathrm{~m}^{2}\right]^{-1}$ ). The arithmetic mean of all stations sampled during a survey was calculated as an index of abundance for the randomly distributed population on the whole area at high water. For more information see Zijlstra et al. (1982) and van der Veer (1986).
Table 1. Positions of stations of water temperature measurements from weekly NOAA satellite composites

\begin{tabular}{|lcc|}
\hline Stn & Latitude $\left({ }^{\circ} \mathrm{N}\right)$ & Longitude $\left({ }^{\circ} \mathrm{E}\right)$ \\
\hline 1 & $51^{\circ} 19^{\prime} 01.7^{\prime \prime}$ & $1^{\circ} 53^{\prime} 12.5^{\prime \prime}$ \\
2 & $51^{\circ} 55^{\prime} 24.2^{\prime \prime}$ & $2^{\circ} 26^{\prime} 39.0^{\prime \prime}$ \\
3 & $52^{\circ} 31^{\prime} 47.3^{\prime \prime}$ & $2^{\circ} 58^{\prime} 35.6^{\prime \prime}$ \\
4 & $53^{\circ} 08^{\prime} 13.0^{\prime \prime}$ & $3^{\circ} 28^{\prime} 57.4^{\prime \prime}$ \\
\hline
\end{tabular}

All demersal settled plaice $\leq 15 \mathrm{~mm}$ were considered to represent settling and just-settled larvae, according to van der Veer (1986). The 2 highest mean densities at Balgzand during the sampling period were taken as an index of year-class strength of plaice, following Zijlstra et al. (1982) and van der Veer (1986).

\section{RESULTS}

\section{Water temperature data}

There was a significantly positive linear relationship between the February water temperature at lightvessel 'Noordhinder' and the temperature on the spawning grounds and a similar, but weaker, relationship occurred with the water temperature at Den Helder and 't Horntje (Table 2). Mean February water temperatures showed less interannual variability on the spawning grounds and at lightvessel 'Noordhinder' than near the entrance of the Wadden Sea at Den Helder and 't Horntje (Fig. 2). Between 1991 and 1997 (1992 excluded), the winter of 1995 was relatively warm, the mean February water temperature at 't Horntje was $5.8^{\circ} \mathrm{C}$, and 1996 was extremely cold with a mean February water temperature of $-0.9^{\circ} \mathrm{C}$. The other years could be classified as intermediate (Fig. 2). Temperature readings from the satellite images were reliable and comparable with the field measurements. Both resulted in a similar and significant relationship between the water temperature at the spawning grounds and those at the lightvessel 'Noordhinder' (Fig. 3).

Table 2. Linear relationships between mean monthly water temperature $\left({ }^{\circ} \mathrm{C}\right)$ in February at the Southern Bight spawning grounds $(\mathrm{SB})$ and at various other sampling stations $(X)$, according to $\mathrm{SB}=a \cdot X+b$ together with correlation coefficient $\left(\mathrm{r}^{2}\right)$ and number of observations ( $\left.\mathrm{n}\right)$. For more information see 'Results'

\begin{tabular}{|lcccc|}
\hline & $a$ & $b$ & $r^{2}$ & $\mathrm{n}$ \\
\hline Lightvessel 'Noordhinder' & 0.914 & 0.500 & 0.91 & 25 \\
Den Helder & 0.645 & 4.485 & 0.65 & 26 \\
tt Horntje & 0.622 & 4.730 & 0.63 & 26 \\
\hline
\end{tabular}




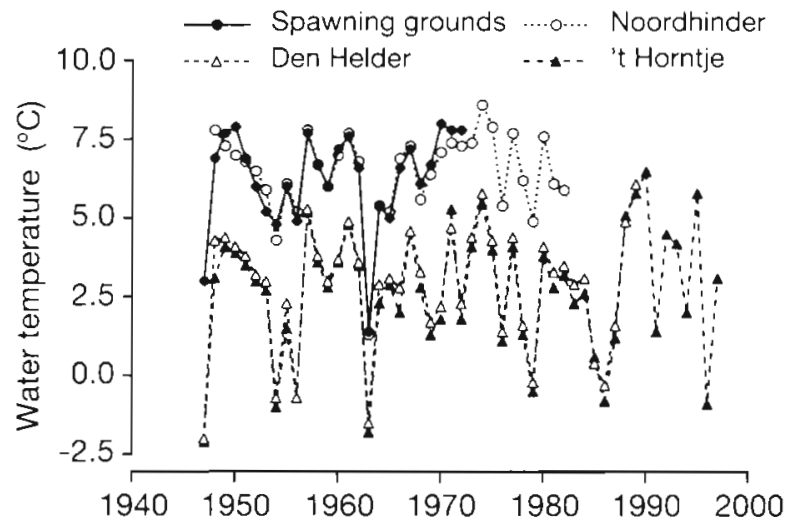

Fig. 2. Mean monthly seawater temperature $\left({ }^{\circ} \mathrm{C}\right)$ in February at the various stations in the southern North Sea. For exact position see Fig. 1a and Table 1

The monthly composites of night satellite images showed that the winter water temperatures in the central part of the southern North Sea were less variable than those in the coastal zone (Fig. 4). In all years a tongue of English Channel water (temperature about $9^{\circ} \mathrm{C}$ ) entering the southern North Sea was observed. The length of this plume in winter varied between years. In warm periods the plume extended into the German Bight as far as Helgoland (March 1995) and during the coldest winter it still penetrated as far as offshore Texel and the Marsdiep inlet. In the open sea, the winter of 1995 showed relatively the highest February temperatures. 1991 and 1997 had the lowest February water temperatures, in contrast to the situation in the coastal area, where the lowest temperatures occurred in 1996.

The weekly mean water temperatures at the 4 stations in the centre of the plume on the transect between the spawning area and the Marsdiep inlet showed a slight decrease in temperature of 1 to $2^{\circ} \mathrm{C}$ from Stns 1 to 4 . At all stations in all years, lowest temperatures occurred between late February and the beginning of April (Fig. 5). Temperature differences between years were small (in the order of a few ${ }^{\circ} \mathrm{C}$ ), except for 1991 in which the temperature was 3 to $4^{\circ} \mathrm{C}$ lower. The interannual variability in temperature was approximately the same for all stations

The patterns of seawater temperature along the transect between the spawning area and the Marsdiep inlet were used to reconstruct the temperature conditions experienced by the various plaice egg and larval batches during development on outlines. Weekly batches were followed, starting from Week 1 (beginning of January) to Week 14 (mid-April). According to Talbot (1978), egg and larval transport from the spawning area towards the Marsdiep inlet takes between 60 and $70 \mathrm{~d}$. We assumed a constant drift of
$63 \mathrm{~d}$, which means that in our simulations eggs spawned in Week 1 at Stn 1 in will 'pass' Stn 2 in Week 4; Stn 3 in Week 7 and Stn 4 in Week 10. The corresponding temperatures were taken from Fig 5. The water temperatures experienced by batches spawned during the other weeks were reconstructed in a similar way (Fig. 6). In all years, the water temperature experienced by the eggs and larvae during drift decreased until the beginning of March, thereafter temperatures increased. On average, water temperature during egg and larval drift varied between 5 and $9^{\circ} \mathrm{C}$, however, in 1991 it declined to $4^{\circ} \mathrm{C}$.

Next, the overall temperature experienced by each batch during drift was estimated. The median temperature was taken, because plaice egg and larval development is inversely log-linear related with temperature (Talbot 1978) (Fig. 7). In all years, the median temperature during development was lowest for batches spawned in February. Differences between years were observed, whereby the median developmental temperature in 1991 was much lower than in the other years. According to Talbot (1978), a median developmental temperature of $7^{\circ} \mathrm{C}$ is required to reach the larval settlement Stages $4 \mathrm{a}$ and $4 \mathrm{~b}$ within a period of 60 to $70 \mathrm{~d}$. This suggests that, in some years, egg batches that were spawned in the beginning of February experienced temperatures that were too low for the completion of development before arriving at the Marsdiep inlet.

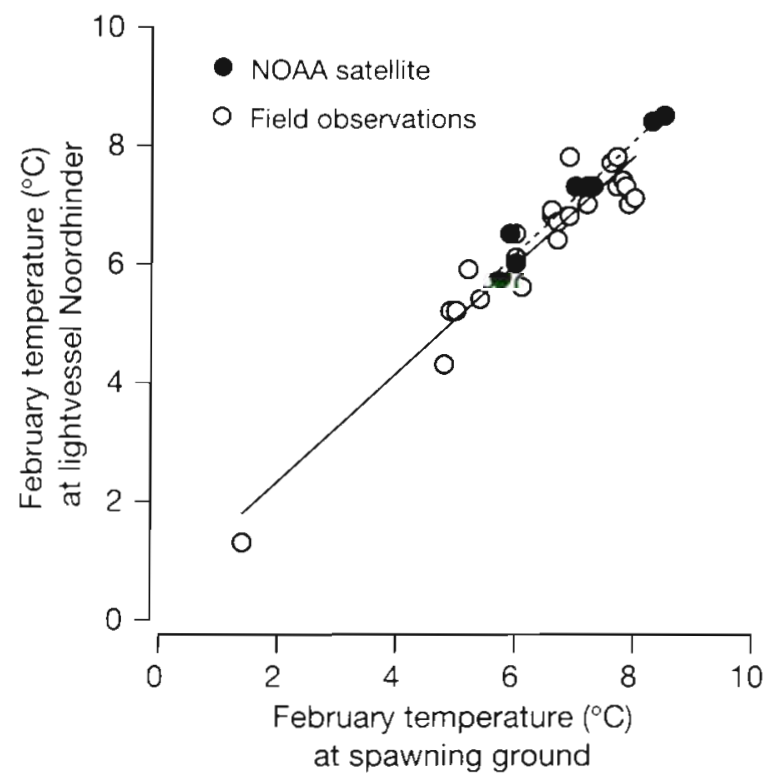

Fig. 3. Relationship between the mean water temperature $\left({ }^{\circ} \mathrm{C}\right)$ in February at the spawning ground of plaice in the Southern Bight and the location of lightvessel 'Noordhinder' Open symbols and solid line: data from field observations (1947-1972): closed symbols and dotted line: data from NOAA satellite monthly composites of night images (1991-1997) 


\section{Flatfish data}

In all years, settlement started at the beginning of March with peak densities in the period end of March to mid-April, ending in May (Fig. 8). In 1994, an early peak in settlement in March as well as a second peak in April were found. Interannual variability in peak settlement was between 200 and 400 ind $\left(10^{3} \mathrm{~m}^{2}\right)^{-1}$, except for 1996 in which the year class was exceptionaily strong; peak settlement amounted more than 1000 ind. $\left(10^{3} \mathrm{~m}^{2}\right)^{-1}$. In 1996 , settlement started in the beginning of March and it continued until the end of May. In all other years, settlement was completed by the beginning of May.

Year-class strength of 0-group plaice at Balgzand varied considerably between years (Fig. 8). Lowest maximum numbers were observed in 1995 (approx. 225 ind. $\left.\left[10^{3} \mathrm{~m}^{2}\right]^{-1}\right)$, while the strongest year class occurred in 1996 (greater than 1000 ind. $\left[10^{3} \mathrm{~m}^{2}\right]^{-1}$ ). In all years the seasonal pattern of abundance was the same with increasing numbers from the beginning of March to May, followed by a rapid reduction in numbers to low densities from the end of June onwards. In 1991 the seasonal pattern in abundance of plaice was not followed, only the maximum density was determined. Peak densities in 1991 was 425 ind. $\left(10^{3} \mathrm{~m}^{2}\right)^{-1}$

\section{Relationship between water temperature and year-class strength}

Year-class strength showed a significantly inverse relationship (Spearman rank correlation $\mathrm{r}_{\mathrm{s}}=-0.89$, $\mathrm{n}=7 ; \mathrm{p}<0.01$ ) with the February water temperature at the spawning ground of the Southern Bight (Fig. 9a). The February water temperature at the spawning ground of the Southern Bight was estimated from the February temperature at 't Horntje and the relationships given in Table 2 , in a similar way as done by van der Veer (1986) for the 1974-1982 period. The inverse relationship between year-class strength and water temperature was also significant if only the peak densities were used $\left(r_{s}=-0.89, n=7 ; p<0.01\right)$ rather than the mean of the 2 highest densities. The robustness of the inverse relationship was further implied as there was still a significant relationship after eliminating the extremely strong 1996 year class (mean of the 2 highest densities, as well as peak density: $\mathrm{r}_{\mathrm{s}}=-0.83, \mathrm{n}=6$; $p<0.05)$. However, the NOAA satellite images showed that the water temperatures experienced by the developing eggs and larvae differed from those estimated from the February temperature at 't Horntje. Therefore, the year-class strength of plaice was related to the real water temperatures experienced at the open sea. Instead of the February water temperature, the median water temperature experienced by the egg batch released at peak spawning (21 January, according to Harding et al. 1978) was taken (data of Batch No. 3 in Fig. 7). 1998 was excluded because no NOAA satellite images were available. The inverse relationship between water temperature during drift and year-class strength was no longer statistically significant $\left(\mathrm{r}_{\mathrm{s}}=\right.$ $-0.49, \mathrm{n}=6$; $\mathrm{p}<0.01$ ), however, when the extremely strong year-class of 1996 was omitted the relationship became stronger $\left(r_{s}=-0.80, n=5\right)$ and more similar to the one based on the estimated February temperatures at the spawning ground (Fig. 9b). The median water temperature experienced during drift, calculated from the NOAA satellite images, showed only a weak relationship with the estimated February temperature at the spawning grounds (Fig. 9c).

Fig. 10 shows the relationship between median water temperature during development and number of settlers at Balgzand during the period of immigration for all years (1993 to 1997) combined. The number of settlers was taken from Fig 8a. The corresponding median water temperatures during development were reconstructed from Fig. 7 , taking the batch number that was hatched $70 \mathrm{~d}$ earlier. This period of $70 \mathrm{~d}$ was based on the assumption of a constant period of drift of 63 d (Harding et al. 1978), corrected for frequency of fishing of once every $14 \mathrm{~d}$, which means a mean age of the settlers of $7 \mathrm{~d}$. A very strong statistically significant inverse relationship between the number of settlers and median water temperature during development was found $\left(\mathrm{r}_{\mathrm{s}}=-0.52, \mathrm{n}=25 ; \mathrm{p}<0.005\right)$. In two years $(1995,1996)$, this relationship could also be observed within a year.

An independent estimate of the mean period of egg and larval drift and corresponding median water temperature during drift is provided by the time differences between the date of peak spawning (21 January $\pm 1 \mathrm{wk}$, Harding et al. 1978) and the date of peak density of settling larvae (Fig. 11a). This estimate of the mean period of drift varied between years from $60 \mathrm{~d}$ in 1995 and $84 \mathrm{~d}$ in 1993. The corresponding required median temperatures to complete development to Stages $4 \mathrm{a}$ and $4 \mathrm{~b}$ during such a period of drift are presented in Fig $11 \mathrm{~b}$. This median temperature differed between $7.4^{\circ} \mathrm{C}$ in 1993 and $9.2^{\circ} \mathrm{C}$ in 1995 . These estimates were within the range of those based on the NOAA satellite images (Fig. 7).

\section{DISCUSSION}

\section{Year-class strength}

The data set for the years 1991 to 1998 confirms and validates the earlier observation of a strong and sig- 
1991
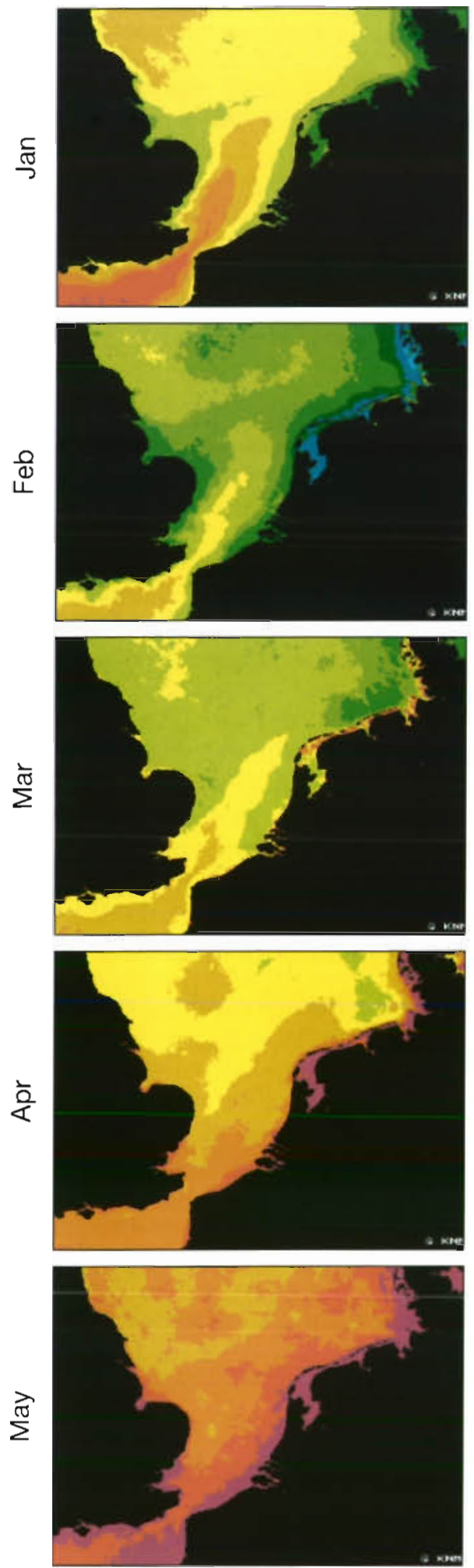

1993
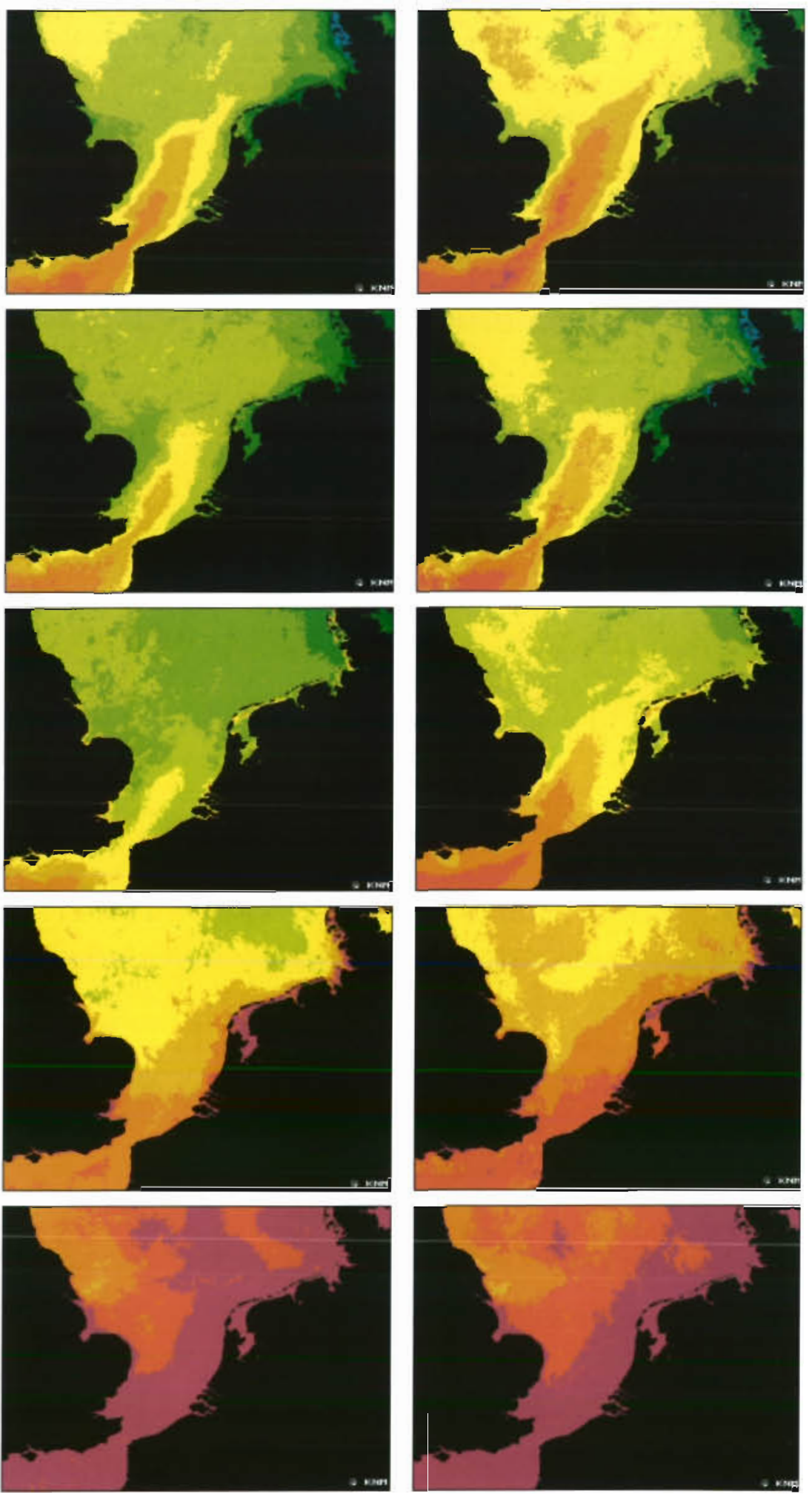
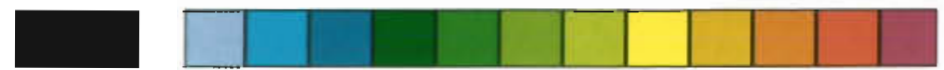

$\begin{array}{llllllllllllll}\text { LAND } & -1 & 0 & 1 & 2 & 3 & 4 & 5 & 6 & 7 & 8 & 9 & 10 & 11^{\circ} \mathrm{C}\end{array}$ 
1995
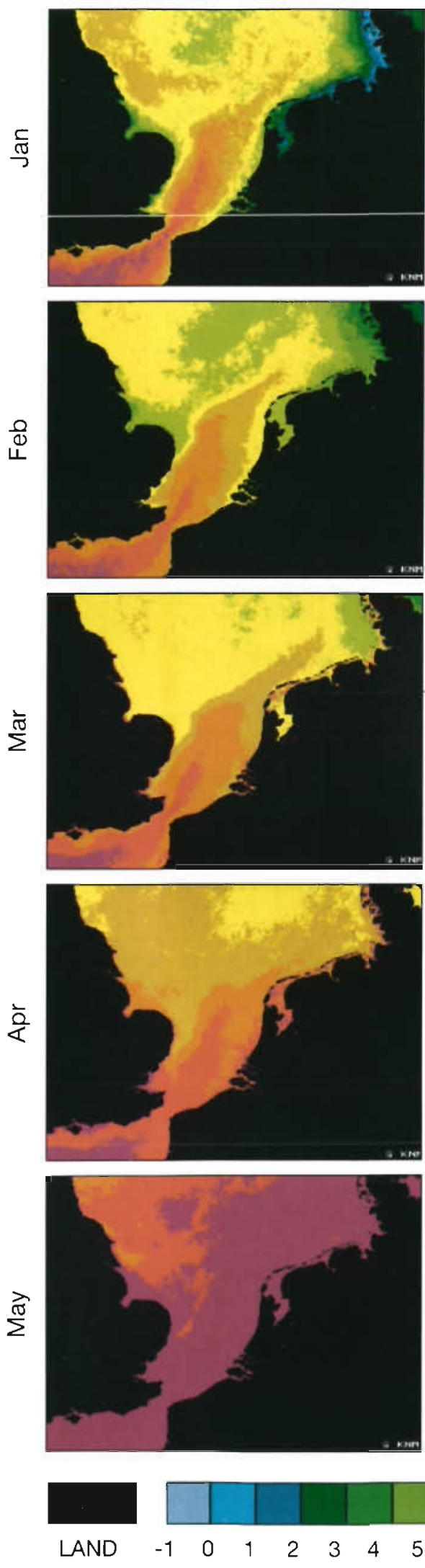

1996
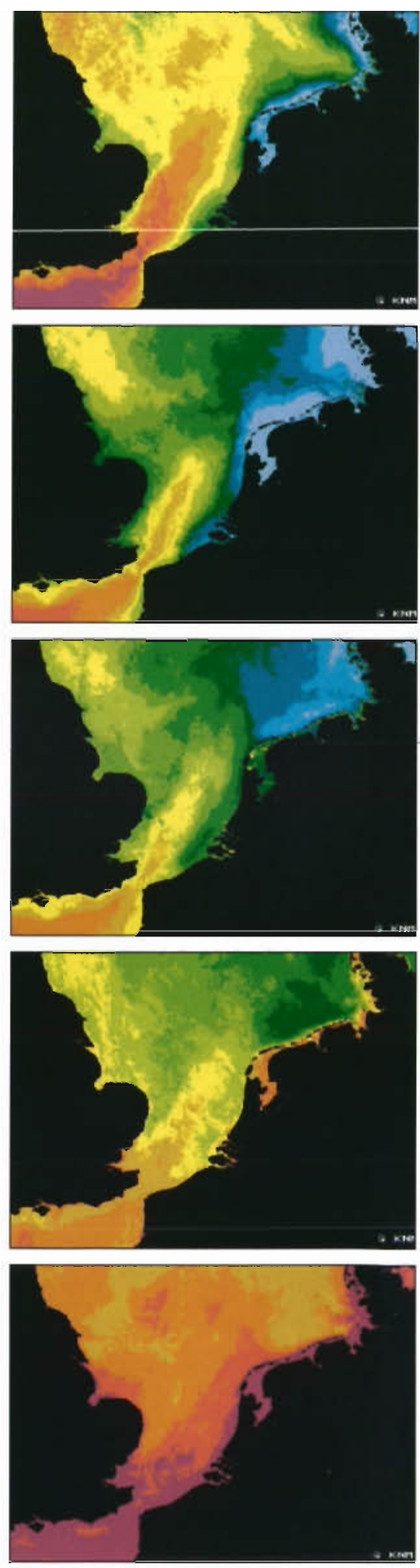

1997
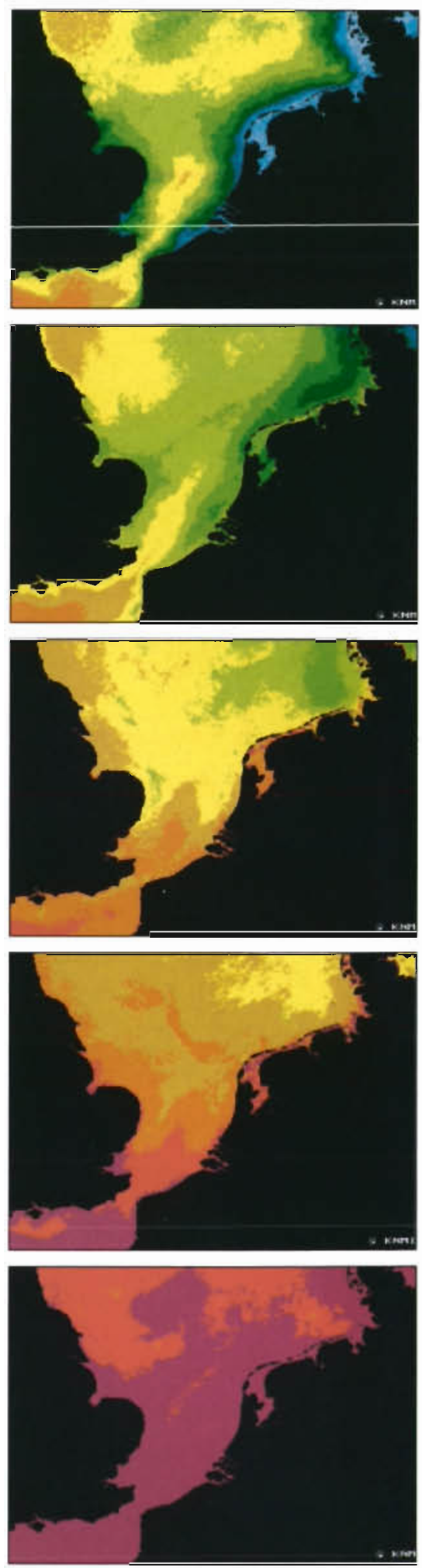

Fig. 4. Monthly composites of night NOAA satellite images of the sea surface temperature $\left({ }^{\circ} \mathrm{C}\right)$ in the southern North Sea for the period January-June 1991 to 1997 (1992 excluded) 

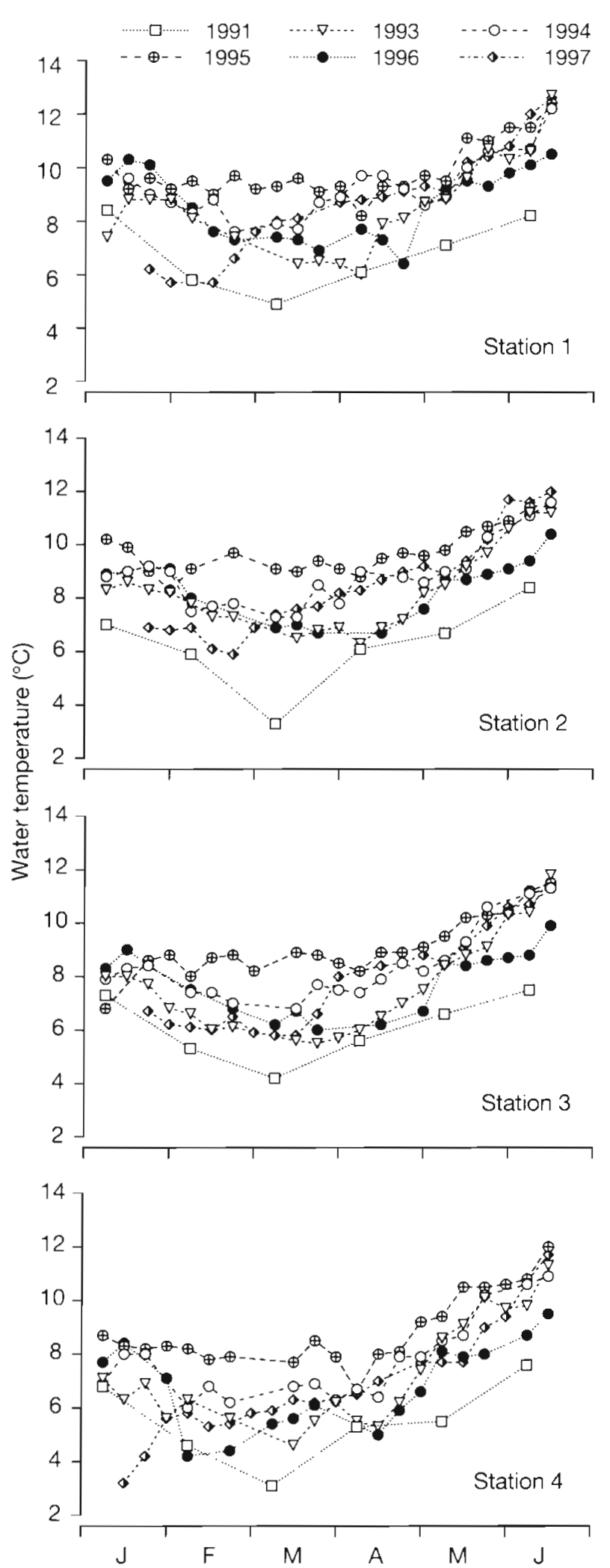

Fig. 5. Weekly mean seawater surface temperatures $\left({ }^{\circ} \mathrm{C}\right)$ at the 4 stations on the transect from the spawning area towards the Marsdiep inlet. Data based on NOAA satellite images. For exact position of the stations see Fig. 1 a and Table 1
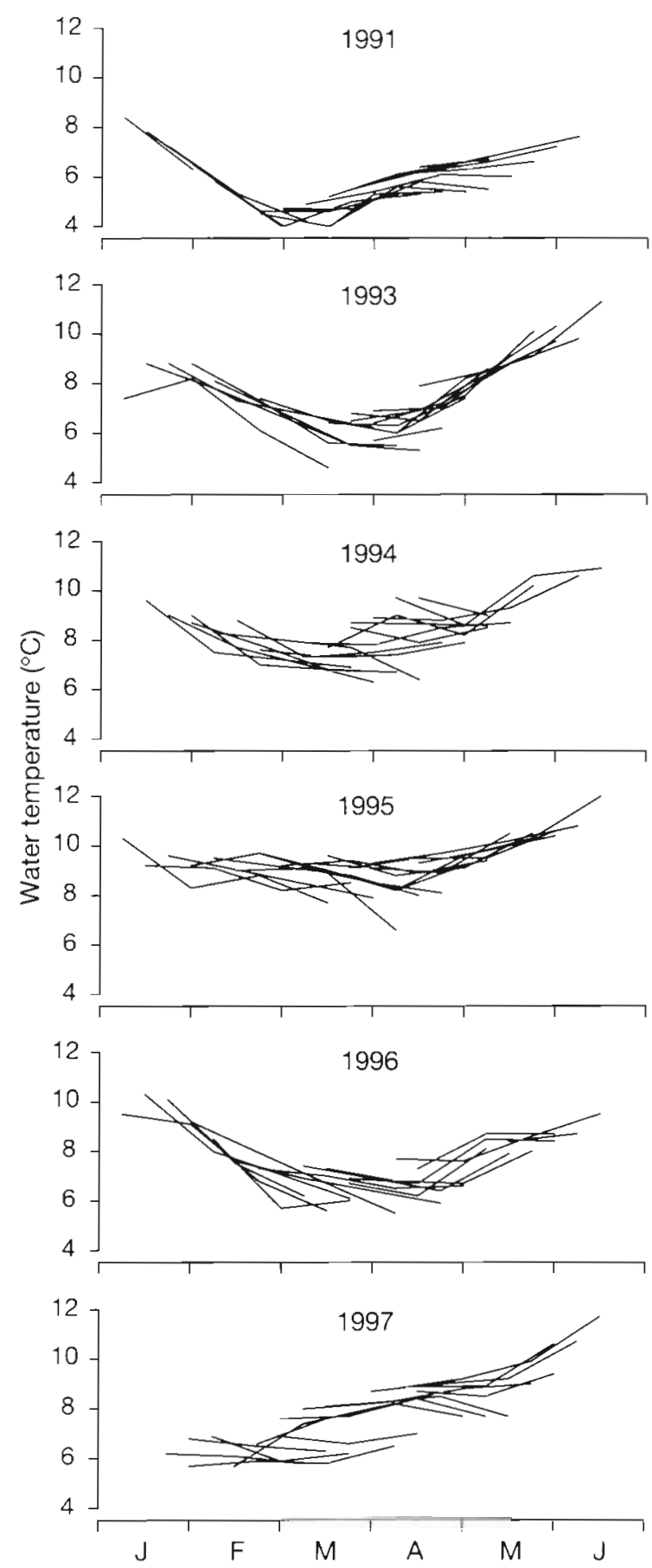

Fig. 6. Reconstructed water temperature history $\left({ }^{\circ} \mathrm{C}\right)$ of plaice eggs and larvae during transport from the spawning areas towards the Marsdiep inlet. Weekly release of batches was simulated over the period 1 January to mid-April under the assumption of a constant period of drift of $63 \mathrm{~d}$ (Harding et al. 1978). For more information see 'Results'

nificant inverse relationship between February winter temperature at the spawning ground and subsequent year-class strength of 0 -group plaice at Balgzand. However, the NOAA satellite images show that the 


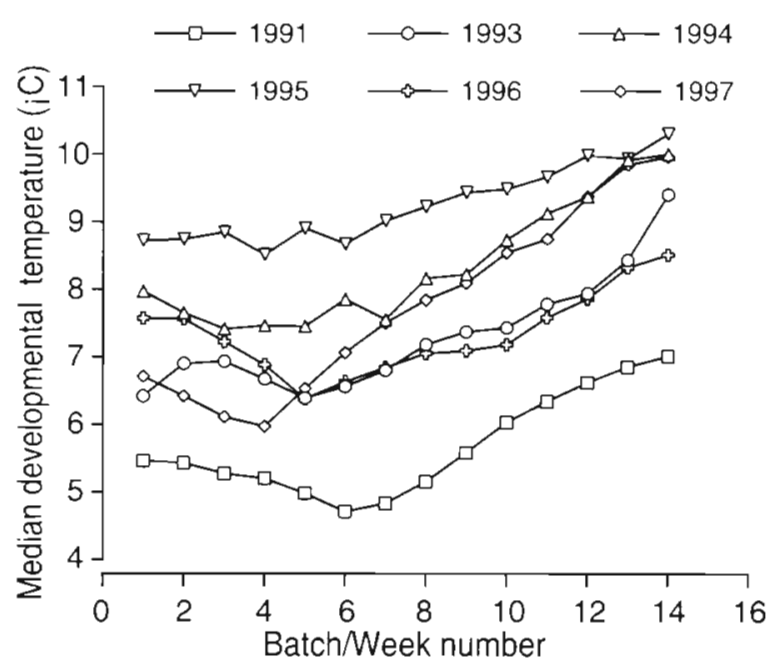

Fig. 7. Estimated median temperature $\left({ }^{\circ} \mathrm{C}\right)$ during egg and larval development from the spawning grounds to off the Marsdiep inlet for batches spawned from the beginning of January (Week 1) to mid-April (Week 14) under the assumption of a constant period of drift of $63 \mathrm{~d}$. Estimates are based on the data of Fig. 6. For more information see 'Results'

water temperatures experienced by the developing eggs and larvae in the open sea differ from those estimated from the February temperature. Records in the coastal zone show larger differences in winter temperature over the years than temperature records in the open sea do. The hydrodynamic circulation pattern in the Southern Bight of the North Sea in winter appears to be relatively stable between years. In all years, a persistent tongue of English Channel water enters through the Dover Strait into the Southern Bight of the North Sea. The intensity of the plume varied between years, but even during cold periods it penetrates as far as offshore Texel and the Marsdiep inlet. Correlations between the median water temperature in this plume during drift and subsequent year-class strength of settled plaice at Balgzand still suggest an inverse relationship, however, it was no longer statistically significant. Such an inverse relationship is in accordance with the results of previous work in the same area (Harding et al. 1978). Mortality curves of plaice eggs in the Southern Bight for 11 yr between 1947 and 1971 showed that better survival rates were associated with reduced water temperatures. Further support for the suggestion that temperature must be an important factor in determining year-class strength in plaice is provided by the very strong inverse relationship in this study between the abundance of the various batches of settling larvae in spring at Balgzand over the years and their reconstructed temperature during development. This relationship could even be observed within a year, both in 1995, a weak, and in 1996, the exceptionally strong, year class.
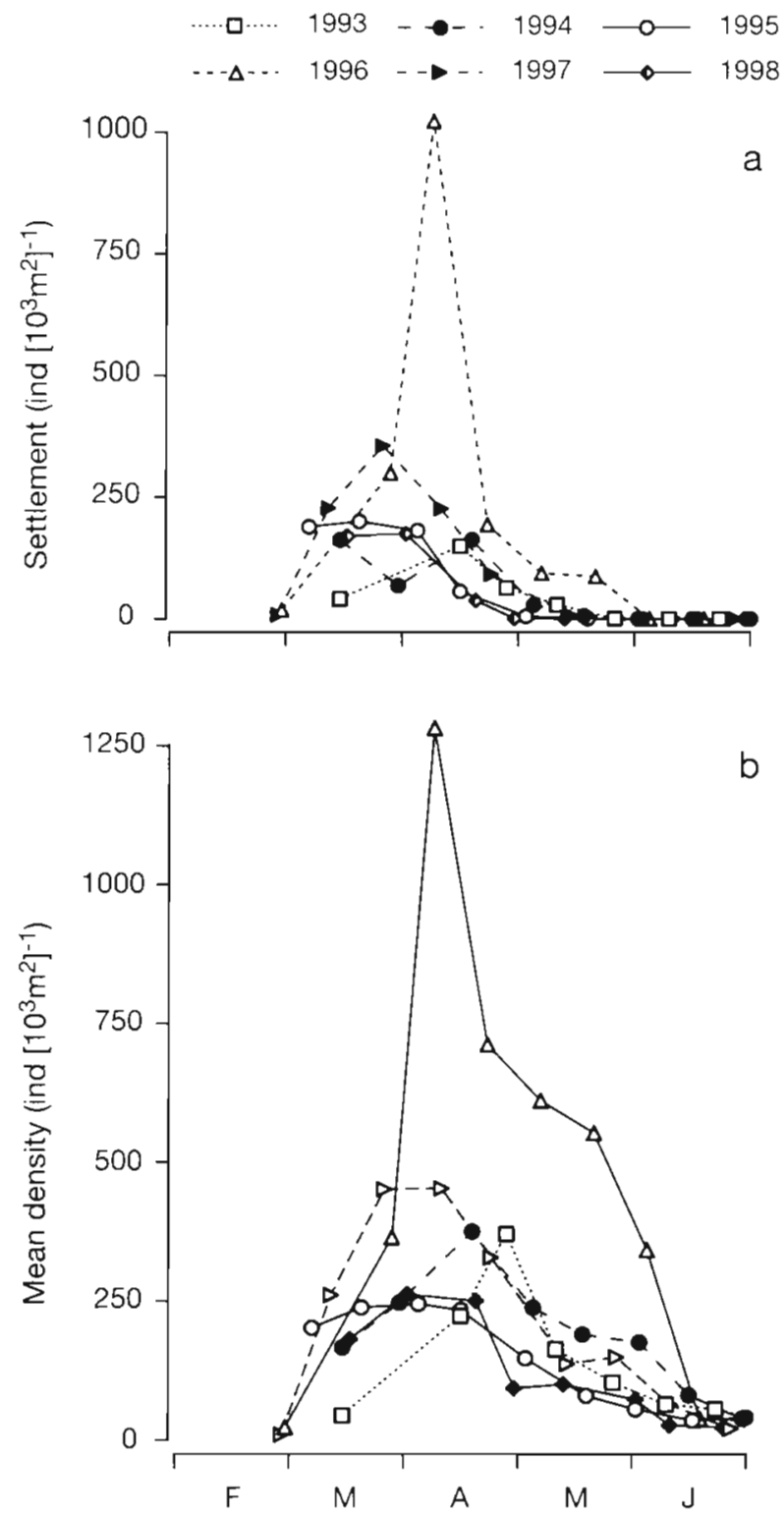

Fig. 8. (a) Settlement patterns of plaice larvae at the Balgzand (ind. $\left[10^{3} \mathrm{~m}^{2}\right]^{-1}$ ) based on the densities of just-settled individuals ( $\leq 15 \mathrm{~mm}$ ) following van der Veer (1986). (b) Seasonal pattern of density (ind. $\left[10^{3} \mathrm{~m}^{2}\right]^{-1}$ ) of 0 -group plaice at the Balgzand

Whether the relationship between temperature and year-class strength is caused directly by temperature affecting egg survival (Zijlstra \& Witte 1982, 1985), or indirectly by temperature controlling metabolism and growth of the larvae (Hovenkamp 1989, 1991) and food uptake of the potential predators (Bannister et al. 1974, van der Land 1991) is still open to debate. With decreasing water temperature the occurrence of malformation in flatfish eggs is strongly reduced (Dethlefsen. et al. 1996). Furthermore, Fonds (1995) and Henderson (1998) suggest that the observed negative relationship 

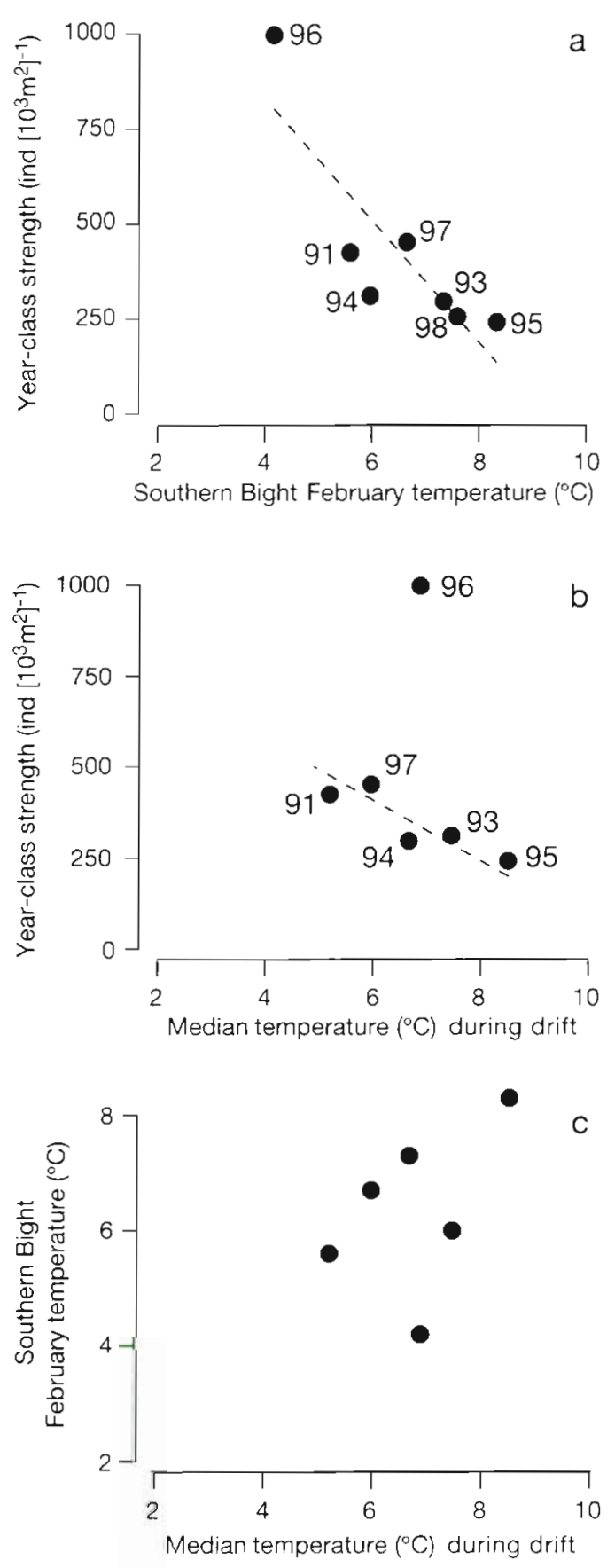

Fig. 9. (a) Relationship between year-class strength of 0-group plaice at Balgzand (ind. $\left.\left[10^{3} \mathrm{~m}^{2}\right]^{-1}\right)$, expressed as the mean of the 2 highest densities, and February water temperature $\left({ }^{\circ} \mathrm{C}\right)$ at the spawning grounds in the Southern Bight of the North Sea, calculated from the February temperature at 't Horntje. (b) Relationship between year-class strength of 0-group plaice at Balgzand (ind. $\left\{10^{3} \mathrm{~m}^{2}\right\}$ ), expressed as the mean of the 2 highest densities, and the median water temperature $\left({ }^{\circ} \mathrm{C}\right)$ experienced by the batch released at peak spawning $(21$ January, according to Harding et al. 1978). Data were taken from Fig. 7 (Batch No. 3). (c) Relationship between the median water temperature $\left({ }^{\circ} \mathrm{C}\right)$ experienced during drift calculated from the NOAA satellite images and the estimated February temperature $\left({ }^{\circ} \mathrm{C}\right)$ at the spawning grounds

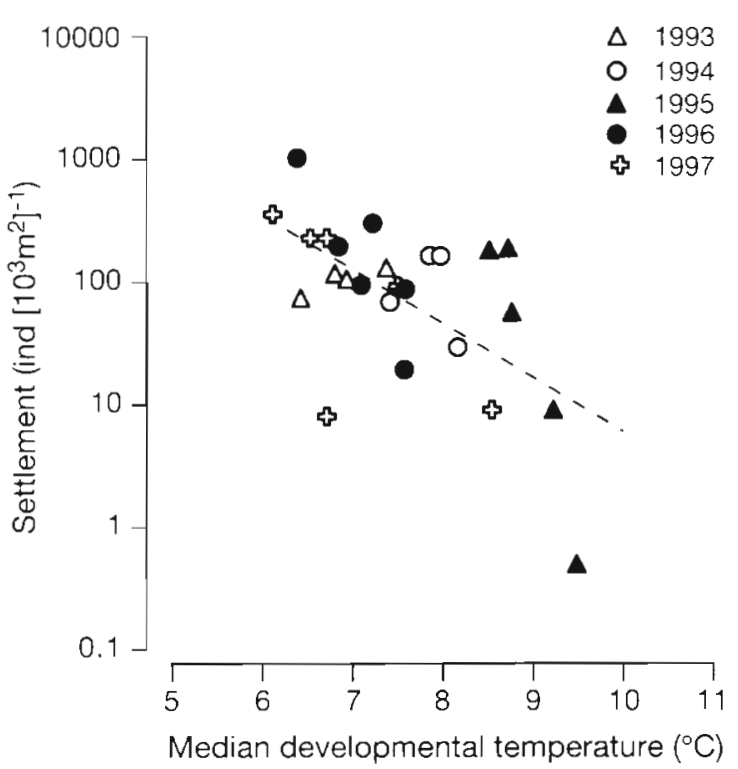

Fig. 10. Relationship between median water temperature $\left({ }^{\circ} \mathrm{C}\right)$ during development and number of settlers (ind. $\left[10^{3} \mathrm{~m}^{2}\right]^{-1}$ ) at Balgzand for all years (1993-1997) combined. Number of settlers were taken from Fig. 8a. The corresponding median water temperatures $\left({ }^{\circ} \mathrm{C}\right)$ during development were reconstructed from Fig. 7. For more information see 'Results'

between survival of eggs and water temperature might be caused by a reduced activity of pathogenic bacteria at low temperatures. The argument against the importance of a reduced predation at low temperatures has always been that it is counteracted at the same time by the prolonged egg and larval development time.

In the exceptionally strong 1996 year class, on the one hand the abundance of the various batches of settling larvae in spring at Balgzand was inversely related to the reconstructed temperature during development, but on the other hand the overall estimate of year-class strength did not fit in the inverse relationship with temperature, because development in 1996 did not take place at low water temperatures. The fact that the inverse relationship breaks down for the very strong 1996 year class suggests that other factors are acting too. Water temperature in the coastal zone in winter is also a reflection of the general weather patterns (Otto et al. 1990), influencing and determining the general circulation pattern in the southern North Sea. Cold winters are often connected with a polar anticyclone over the northern North Sea, resulting in persistent winds from the east. If they occur over a long period of time they lead to an atypical water circulation pattern, affecting the strength and direction of the residual currents. Also in the Kattegat, Nielsen et al. (1998) found evidence that the abundance of settled 0 -group plaice along the Danish coast depended on egg and larval transport from the Skagerrak. Similarly, van der Veer 
et al. (1998) working with a realistic 2-D circulation model for the southern North Sea showed that winddriven variability in circulation patterns during the early pelagic stages in the open sea might be a key factor in determining subsequent year-class strength of settling plaice in the nursery areas. Furthermore, cold winters are associated with persistent winds from the east and these winds might generate upwelling near the coast. Since the larvae are thought to reach the coastal nursery areas by an inshore flow at depth (Cushing 1990), such upwelling might also stimulate larval immigration.

Year-to-year variability in temperature has been shown to be linked with year-class strength also in a number of other fish species (Frank 1991, Planque \& Fox 1998), but the correlation appears to vary over the range of distribution. Positive relationships occur near the northern (cold water) limits, negative relationships are found near the southern (warm water) limits and no relationship is observed in the centre of the distribution (Frank 1991). Plaice is a cold-water species and occurs from the Barents Sea to Portugal. The Southern Bight population is located at the southern part of the range and the inverse relationship of winter temperature and year-class strength supports the view of Frank
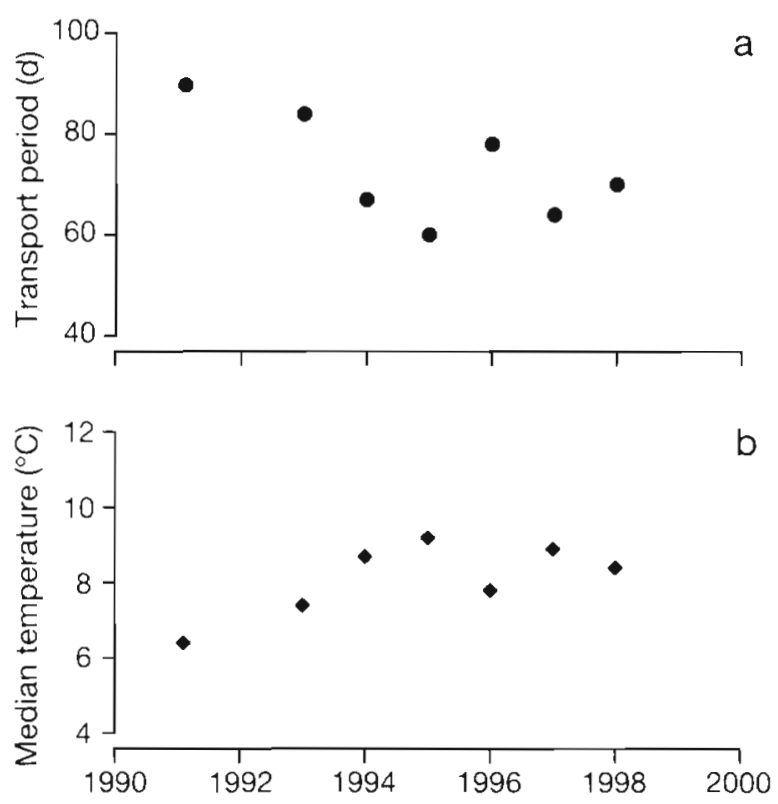

Fig. 11. (a) Estimated mean period of drift (days) of the main patch of developing plaice, calculated from the time difference between peak spawning ( 21 January \pm 1 wk, according to Harding et al. 1978) and date of peak density of immigrating larvae (settled ind. $\leq 15 \mathrm{~mm}$, according to van der Veer 1986) for the years 1991 to 1998 (1992 excluded). (b) Estimated required median temperatures $\left({ }^{\circ} \mathrm{C}\right)$ to complete development to Stages $4 \mathrm{a}$ and $4 \mathrm{~b}$ during the period of drift as calculated above
(1991). In another cold-water species at the southern edge of its distribution, Irish Sea cod, a strong inverse relationship between temperature and recruitment was also found (Planque \& Fox 1998).

Recently, Lange \& Greve (1997) proposed that temperature acts before spawning on gonadal maturation, which - if one supposes that a fish species has a bellshape-like distribution over the temperature rangein their view would also explain the positive relationship with temperature near the cold water limit and the negative relationship near the warm-water limit. At the cold edge of the distribution, a decrease in temperature would reduce recruitment because the resultant delayed spawning would lead to a shift to a more unfavourable season, and at the warm edge, it would increase recruitment because the resultant premature spawning time will lead to a shift towards a more favourable season. Rijnsdorp \& Vethaak (1997) indeed observed in Southern Bight plaice a delay of the start and the end of spawning at low water temperatures.

\section{Development and drift}

The estimates of the water temperature conditions experienced are based on the assumption that the period of drift is constant (63 d), however, in reality the period of drift will vary (Talbot 1978). Nevertheless, the overall estimate of median water temperature experienced during drift will hardly be affected even by a variation of a few weeks in drift since the fluctuations in water temperature are in the order of only 1 to $2^{\circ} \mathrm{C} \mathrm{mo}{ }^{-1}$. Therefore, the temperature estimates will be robust. Differences in temperature during drift generate differences in development time of plaice (Ryland 1966, Ryland et al. 1975), but despite the interannual differences in temperature no differences between years are found with respect to morphological stage, larvae size at the time of immigration or the timing of immigration.

This study shows that this apparent discrepancy is less serious than previously thought (van der Veer 1986). Temperature differences between years in the open sea are much smaller than the coastal zone records suggested. Nevertheless, differences in temperature of between 6.5 and $10^{\circ} \mathrm{C}$ still occur and the absence of interruptions in the pattern of larval immigrations suggests that the variations in median water temperatures are compensated for by a difference in the period of drift. According to Harding et al. (1978) and Rijnsdorp \& Vethaak (1997) the timing of peak spawning of plaice in the Southern Bight is fixed. Therefore, the differences in timing of the peak density of settling larvae at the Balgzand over the years indicate that the period of drift indeed varies. Observations 
of the fluctuations in electromagnetic field induced in the Dover-Sangatte telephone cable (Talbot 1978) have shown that variability occurs in Southern Bight residual current strength and direction. Modelling studies on the interactions of wind-and density-driven currents in the southern North Sea show that the circulation in the North Sea can be reversed by wind. Southwesterly wind generates a flow in a northeasterly direction along the coast, and the reverse situation occurs under the influence of a northeasterly wind (Langenberg 1997).

There are indications that occasionally larval development is not completed by the time that the larvae arrive at the Marsdiep. Van der Veer (1986) observed a cessation of plaice settlement over a period of $2 \mathrm{wk}$ in 1 yr of his study (1982). The present data do not support this finding. Also, larval drift appears to vary over the years. Beverton \& Lee (1965) compared the larval drift in a normal winter (1962) with that of a very cold winter (1963) and found that in a normal year larvae drifted towards the Dutch coast and the Marsdiep inlet, whereas in a cold winter drift was further to the north, into the German Bight. However, this does not exclude the possibility that in 1963 larvae also settled in the Marsdiep area. At the other extreme, there are also some indications that larval development is completed before arriving at the Marsdiep inlet. Towards the end of spawning when water temperatures start to increase, the required period of drift decreases in all years down to approximately $50 \mathrm{~d}$. In a previous study it was suggested that larval immigration ended in early May, as a consequence of an outburst of predatory coelenterates, in particular the ctenophore Pleurobrachia pileus (van der Veer 1986). However, the rapid decrease in the required period of drift for these batches may also imply an alternative explanation. They could have completed development long before arriving at the Marsdiep inlet and therefore settled in the coastal zone somewhere between the spawning area and the Marsdiep inlet.

Acknowledgements. Thanks are due to Hans Roozekrans, Royal Netherlands Meteorological Institute (KNMI), for. making available the NOAA satellite images of sea surface temperatures of the southern North Sea, to Taco de Bruin (Data Management Group, NIOZ) for assisting in analysing the satellite images, to Henk Hobbelink for graphical assistance and to Ewout Adriaans, skipper of the RV 'Griend', for assistance during the field work. The comments of Jan Beukema, Richard Nash and the anonymous reviewers improved the manuscript considerably. This is NIOZ publication no. 3344 .

\section{LITERATURE CITED}

Bailey KM (1994) Predation on juvenile flatfish and recruitment variability, Neth J Sea Res 32:175-189

Bannister RCA, Harding D, Lockwood SJ (1974) Larval mortality and subsequent yearclass strength in the plaice
(Pleuronectes platessa L.). In: Blaxter JHS (ed) The early life history of fish. Springer Verlag, Berlin, p 21-37

Beverton RJH, Lee AJ (1965) Hydrographic fluctuations in the North Atlantic Ocean and some biological consequences. In: Johnson CG, Smith LP (eds) The biological significance of climatic changes in Britain. Academic Press, London, p 79-107

Brander K, Houghton RG (1982) Predicting the recruitment of North Sea plaice from egg surveys. ICES CM/G:5, p 1-3

Creutzberg F, Eltink ATGW, Van Noort GJ (1.978) The migration of plaice larvae Pleuronectes platessa into the western Wadden Sea. In: McLusky DS, Berry AJ (eds) Physiology and behaviour of marine organisms. Proc 12th Eur Mar Biol Symp. Pergamon Press, New York, p 243-251

Cushing DH (1990) Hydrographic containment of a spawning group of plaice in the Southern Bight of the North Sea. Mar Ecol Prog Ser 58:287-297

Dapper R (1978) De Balgzand scholgegevens 1975, 1976 , 1977. Neth J Sea Res Intern Rep 1978-12:1-53

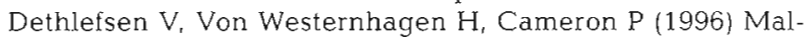
formations in North Sea pelagic fish embryos during the period 1984-1995. ICES J Mar Sci 53:1024-1035

Fonds M (1995) Effect of winter temperature on the brood success of flatfish. Annual Report 1995, Neth Inst Sea Res, Texel

Frank KT (1991) Predicting recruitment variation from year class specific vertebral counts: an analysis of the potential and a plan for verification. Can J Fish Aquat Sci 48: $1350-1357$

Gulland JA (1965) Survival of the youngest stages of fish and its relation to year-class strength. Publs Int Commn NW Atlant Fish 6:365-371

Harding D, Talbot JW (1973) Recent studies on the eggs and larvae of the plaice (Pleuronectes platessa L.) in the Southern Bight. Rapp P-V Réun Cons Int Explor Mer 164:261-269

Harding D. Nichols JH. Tungate DS (1978) The spawning of the plaice (Pleuronectes platessa L.) in the Southern North Sea and the English Channel. Rapp P-V Réun Cons Int Explor Mer 172:102-113

Henderson P (1998) On the variation in dab Limanda limanda recruitment: a zoogeographic study. J Sea Res 40:131-142

Hovenkamp F (1989) Within-season variation of larval plaice (Pleuronectes platessa L.). Rapp P-V Réun Cons Int Explor Mer 191:248-257

Hovenkamp F (1991) Growth, otolith growth and RNA/DNA ratios of larval plaice Pleuronectes platessa in the North Sea 1987 to 1989. Mar Ecol Prog Ser 70:105-116

Kuipers BR (1975) On the efficiency of a two meter beam trawl in juvenile plaice (Pleuronectes platessa L.). Neth $\mathrm{J}$ Sea Res 9:69-85

Lange U. Greve W (1997) Does temperature influence the spawning time, recruitment and distribution of flatfish via its influence on the rate of gonadal maturation? Ger J Hydrogr 49:251-263

Langenberg H (1997) Interactions of wind and density driven currents in the North Sea ROFIs - a model study. J Mar Syst 12:157-170

Nielsen E, Bagge O, Mackenzie BR (1998) Wind-induced transport of plaice (Pleuronectes platessa): early lifehistory stages in the Skagerrak-Kattegat. J Sea Res 39: $11-28$

Otto L, Zimmerman JTF, Furnes GK, Mork M, Sxetre R, Becker G (1990) Review of the physical oceanography of the North Sea. Neth J Sea Res 26:161-238

Planque B, Fox CJ (1998) Interannual variability in temperature and the recruitment of Irish Sea cod. Mar Ecol Prog Ser 172:101-105 
Rijnsdorp AD, Vethaak AD (1997) Changes in reproductive parameters of North Sea plaice and sole between 1960 and 1995. ICES CM1997/U: 14, p 1-14

Riley JD, Corlett J (1966) The numbers of 0-group plaice in Port Erin Bay, 1964-66. Rep Mar Biol Stn Port Erin 1965 $78: 51-56$

Roozekrans JN, Prangsma GJ (1988) Processing and application of digital AVHRR-imagery for land and sea surfaces. Royal Neth Meteo Inst Intern Rep, BCRS-88-08, p 1-100

Ryland JS (1966) Observations on the development of larvae of the plaice Pleuronectes platessa L. in aquaria. J Cons Perm Int Explor Mer 30:177-195

Ryland JS, Nichols JH, Sykes AM (1975) Effect of temperature on the embryonic development of the plaice Pleuronectes platessa L. (Teleostei). J Exp Mar Biol Ecol 18: $121-137$

Simpson AC (1959) The spawning of the plaice (Pleuronectes platessa) in the North Sea. Fish Invest Ser II 22(7):1-111

Talbot JW (1976) The dispersal of plaice eggs and larvae in the Southern Bight of the North Sea. J Cons Int Explor Mer $37: 221-248$

Talbot JW (1978) Changes in plaice larval dispersal in the last fifteen years. Rapp P.V Réun Cons Int Explor Mer 172: $114-123$

van der Hoeven PCT (1984a) Watertemperatuurwaarnemin-

Editorial responsibility: Otto Kinne (Editor),

Oldendorf/Luhe, Germany gen in Nederland sedert 1860: meetreeksen KNMI-RWS. KNMI WR 84/5:1-83

van der Hoeven PCT (1984b) Watertemperatuurwaarnemingen in Nederland sinds 1860: tabellenboek lichtschepen. KNMI WR 84/4:1-117

van der Land MA (1991) Distribution of flatfish eggs in the 1989 egg surveys in the southeastern North Sea, and mortality of plaice and sole eggs. Neth J Sea Res 27:277-286 van der Veer HW (1986) Immigration, settlement, and density-dependent mortality of a larval and early postlarval 0-group plaice (Pleuronectes platessa) population in the western Dutch Wadden Sea. Mar Ecol Prog Ser 29:223-236 van der Veer HW, Ruardy $P$, Van den Berg AJ, Ridderinkhof $\mathrm{H}$ (1998) Impact of interannual variability in hydrodynamic circulation on egg and larval transport of plaice Pleuronectes platessa L. in the southern North Sea. J Sea Res 39:29-40

Zijlstra JJ, Witte JIJ (1982) On the relation between length and abundance in 0 -group plaice of the North Sea. ICES CM1982/G:4, p $1-7$

Zijlstra JJ, Witte JIJ (1985) On the recruitment of 0-group plaice in the North Sea. Neth J Zool 35:360-376

Zijlstra JJ, Dapper R, Witte JIJ (1982) Settlement, growth and mortality of post-larval plaice (Pleuronectes platessa L.) in the western Wadden Sea. Neth J Sea Res 15:250-272

Submitted: November 6, 1998; Accepted: March 29, 1999

Proofs received from author(s): July 12, 1999 